\title{
Identification of a Novel Pseudomonas syringae Psy61 Effector with Virulence and Avirulence Functions by a HrpL-Dependent Promoter-Trap Assay
}

\author{
L. Losada, T. Sussan, K. Pak, S. Zeyad, I. Rozenbaum, and S. W. Hutcheson \\ Department of Cell Biology and Molecular Genetics, Microbiology Bldg. University of Maryland, College Park 20742, U.S.A.
}

Submitted 24 February 2003. Accepted 30 October 2003.

The hrp pathogenicity island of Pseudomonas syringae encodes a type III secretion system (TTSS) that translocates effectors into plant cells. Most genes encoding effectors are dispersed in the $\boldsymbol{P}$. syringae genome. Regardless of location, all are regulated coordinately by the alternative sigma factor HrpL. An HrpL-dependent promoter-trap assay was developed to screen genomic libraries of $P$. syringae strains for promoters whose activity in Escherichia coli is dependent on an inducible hrpL construct. Twenty-two HrpL-dependent promoter fragments were isolated from $P$. syringae Psy61 that included promoters for known HrpL-dependent genes. One fragment also was isolated that shared no similarity with known genes but retained a near consensus HrpL-dependent promoter. The sequence of the region revealed a 375-amino acid open reading frame encoding a 40.5-kDa product that was designated HopPsyL. HopPsyL was structurally similar to other secreted effectors and carried a putative chloroplast-targeting signal and two predicted transmembrane domains. HopPsyL':'AvrRpt2 fusions were translocated into host cells via the $P$. syringae pv. tomato DC3000 hrp TTSS. A hopPsyL::kan mutant of Psy61 exhibited strongly reduced virulence in Phaseolus vulgaris cv. Kentucky Wonder, but did not appear to act as a defense response suppressor. The ectopically expressed gene reduced the virulence of Pseudomonas syringae DC3000 transformants in Arabidopsis thaliana Col-0. The gene was shown to be conserved in 6 of $10 P$. syringae pv. syringae strains but was not detected in 35 strains of other pathovars. HopPsyL appears to be a novel TTSS-dependent effector that functions as a host-species-specific virulence factor in Psy61.

Pseudomonas syringae is a ubiquitous plant-pathogenic bacterium commonly found as an epiphyte on plant surfaces and capable of causing disease in most agriculturally important plants. Individual $P$. syringae strains, however, exhibit host selectivity, usually causing disease in only a specific subset of plants. The pathogenicity of $P$. syringae strains has been linked to the activities of a gene cluster found in the hrp patho-

Corresponding author: S. W. Hutcheson; E-mail: sh53@umail.umd.edu Telephone: +301.405.5498.

Nucleotide sequence data reported is available in the GenBank database under the accession number AY349161.

* The $\boldsymbol{e}$-Xtra logo stands for "electronic extra" and indicates the HTML abstract available on-line contains supplemental material not included in the print edition. genicity island (Alfano et al. 2000; Hutcheson 1999; Lindgren et al. 1986). These genes encode a type III secretion system (TTSS) (Cornelis and VanGijsegem 2000) as well as several genes for effector proteins that are translocated into adjacent host cells by the TTSS (Collmer et al. 2002; Hutcheson 2001). These effectors are thought to control the host range of a strain. In susceptible plants, effectors function to suppress plant defense responses (Abramovitch et al. 2003; Bretz et al. 2003; Chen et al. 2000; Espinosa et al. 2003; Tsiamis et al. 2000) or stimulate nutrient leakage from the host cell (Lee et al. 2001) to facilitate parasitism of the host. In resistant plants, one or more of the effectors appear to be recognized by host receptors that, in turn, initiate a defense response to inhibit further parasitic growth (Dangl and Jones 2001; Mackey et al. 2002; Scofield et al. 1996; Tang et al. 1996). Genetic evidence suggests that, in order for disease to occur, the pathogen must translocate effectors that promote parasitism without eliciting a rapid defense response (Dangl and Jones 2001).

Identification of the effectors produced by $P$. syringae strains is of high priority to understand their pathogenesis, but this task has been comparatively difficult. Initially, genomic libraries of one strain were screened for $a v r$ genes that alter the host range of another strain (Greenberg and Vinatzer 2003; Leach and White 1996; Staskawicz et al. 1984; Vivian and Gibbon 1997). The products of avr genes subsequently were shown to encode translocated effector proteins (Gopalan et al. 1996; Leister et al. 1996; Pirhonen et al. 1996). In some cases, proteins detected in the growth medium also have been found to be secreted by the TTSS (Yuan and He 1996). A randomly generated fusion to a truncated effector lacking the native secretion domain also has been used to identify effectors (Guttman et al. 2002). Most recently, in silico approaches were used to screen the genome of $P$. syringae pv. tomato DC3000, a pathogen of tomato and Arabidopsis thaliana, and the bean pathogen $P$. syringae pv. syringae B728a for genes that match a set of postulated effector characteristics (Petnicki-Ocweija et al. 2002) or carry conserved promoter sequences unique to the hrp regulon (Fouts et al. 2002; Zwiesler-Vollick et al. 2002). These studies indicate that $P$. syringae strains carry numerous effector genes that are distributed throughout the genome as individual loci (Fouts et al. 2002; Guttman et al. 2002; Kim et al. 1998; Petnicki-Ocweija et al. 2002; Zwiesler-Vollick et al. 2002), clustered with the pathogenicity island (PAI) as assembled "integron-like" modules (Alfano et al. 2000; Charity et al. 2003; Deng et al. 2003; Hutcheson 1999), or found in plasmid-borne gene clusters (Arnold et al. 2001; Jackson et al. 1999).

Although these approaches have established catalogs of the effectors secreted by a few $P$. syringae strains, the effectors produced by most strains still are uncharacterized. Thus, the 
effectors that define the host range of the majority of strains have yet to be established. Genome analysis of multiple strains is limited by its cost, and most other previously employed methods are laborious. Due to the limitations of these approaches, we were interested in developing a more generally applicable method for screening previously uncharacterized $P$. syringae strains for effector genes. A conserved regulatory system has been identified in $P$. syringae (Hutcheson et al. 2001; Xiao et al. 1994) that utilizes HrpL, a conserved alternative sigma factor (Sawada et al. 1999; Xiao et al. 1994; Xiao and Hutcheson 1994), to control the transcription of the hrp operons encoding components of the TTSS as well as all known effector genes (Xiao and Hutcheson 1994). It is likely that the expression of effector genes within uncharacterized strains will be dependent on HrpL, a trait that can be used to identify novel effector genes as observed by others (Fouts et al. 2002; Zwiesler-Vollick et al. 2002). By using an Escherichia coli-based HrpL-dependent promoter-trap assay in a partial screen of the $P$. syringae pv. syringae Psy61 genome, 22 HrpL-dependent promoter fragments were identified. These fragments revealed promoters for previously characterized hrp PAI operons of Psy61, effector genes originally identified in other $P$. syringae strains, and a candidate gene for a novel effector. This candidate gene was shown to produce a translocated effector that is necessary for virulence of Psy61 in bean plants but elicits defense responses in other plants.

\section{RESULTS}

Screen of the Psy61 genome for HrpL-dependent promoters.

Because the genes for all known or candidate effectors of $P$. syringae require the alternative sigma factor $\mathrm{HrpL}$ for expression (Fouts et al. 2002; Xiao and Hutcheson 1994; ZwieslerVollick et al. 2002), we devised an inexpensive plate assay to identify HrpL-dependent promoter fusions to a promoterless 'lacZYA cassette based on the Lac phenotype of E. coli transformants carrying an arabinose-inducible $h r p L$ construct, pSHL4K. The inducible hrpL construct was used to distinguish HrpL-dependent promoter fusions, which produce a $\mathrm{Lac}^{+}$phenotype only in the presence of arabinose, from constitutively expressed promoters of other genes. When several known Psy61 HrpL-dependent promoters cloned into pRG970 were transformed into E. coli SLR400 (pSHL4K), transformants exhibited a $\mathrm{Lac}^{+}$phenotype only on MacConkey lactose plates containing $0.01 \%$ arabinose. These strains exhibited an average 80 -fold increase in $\beta$-galactosidase activity in the presence of L-arabinose.

The assay described above was used to partially screen the Psy61 genome for HrpL-dependent promoters. Psy61 was chosen because the previously identified HrpL-dependent promoters of its hrp PAI could be used as an internal control for the survey (Hutcheson 1999), but the suite of effectors produced by this strain was largely unknown. Genomic libraries carrying 1- to 4-kb fragments of the Psy61 genome were created in pRG970 and transformed into SLR400 (pSHL4K). Transformants initially were screened for Lac phenotypes on MacConkey lactose agar supplemented with L-arabinose to enhance the sensitivity of the screen. Colonies exhibiting any level of $\mathrm{Lac}^{+}$phenotype in this screen were single-colony purified on King's medium B (KB) agar and then screened for arabinose-dependent Lac phenotype in a second-stage screen. Of the 1,200 colonies identified with $\mathrm{Lac}^{+}$phenotypes in the initial stage (approximately 2\% of transformants), 68 exhibited an arabinose-dependent Lac phenotype in the second stage. The genomic inserts carried by the resident plasmid of these colonies then were amplified by polymerase chain reaction (PCR) and the nucleotide sequences of the fragments obtained. Of the 68 fragments sequenced, 22 independently isolated fragments included a known or candidate HrpL-dependent promoter. Promoters for $h r p A, h r p C, h r p K$, and $s h c A$ that had been characterized previously in this strain as well as the promoters for avrE, avrPphB, hopPmaH, or hrpW that had been identified in other $P$. syringae strains were included in these fragments (Table 1). However, one fragment, KP54, revealed no similarities to genes in the databases but contained a strong candidate HrpL-dependent promoter. The majority of the fragments carrying HrpL-dependent promoters exhibited relatively weak $\mathrm{Lac}^{+}$phenotypes in the initial screen.

\section{Identification of the ORF54 product.}

Because of the potential presence of a novel effector, subsequent experiments focused on fragment KP54. The candidate HrpL-dependent promoter carried by this fragment included 11 out of 12 consensus nucleotides identified previously (Xiao and Hutcheson 1994) that form the HrpL-dependent promoter (Table 1). The HrpL-dependent activity of this promoter was confirmed in Psy61. Psy61-2070 (pTS54R) carrying a plasmid-borne KP54-lac $Z$ fusion exhibited $\beta$-galactosidase activity only under hrp-inductive conditions and near basal levels under repressive conditions. This construct was poorly expressed in the hrpL null mutant, Psy61-2074.

A potential open reading frame (ORF), ORF54, was identified $23 \mathrm{bp}$ downstream of the deduced HrpL-dependent promoter. ORF54 was preceded by a strong candidate ribosomebinding site. The predicted ORF54, however, extended past the end of the initially cloned fragment. Thermal asymmetric interlaced (TAIL)-PCR (Liu and Whittier 1995) and inverse PCR (Ochman et al. 1990) were used to determine the remaining sequence of the ORF. ORF54 was found to encode a leucine-rich (12.8\%) 375-amino acid (aa) protein with a predicted molecular weight of $40.5 \mathrm{KDa}$ and a predicted pI of 8.74 (GenBank accession number AY349161). The deduced ORF54

Table 1. Promoter active fragments identified by the HrpL-dependent promoter-trap screen of Psy61

\begin{tabular}{|c|c|c|c|}
\hline Fragment & Homolog $^{x}$ & E value & Promoter $^{y}$ \\
\hline $\mathrm{KP} 1^{\mathrm{z}}$ & HrpA & 0.0 & GGAACCNAN $_{14}$ CCACNNA \\
\hline KP8, KP21 & HopPsyA & 0.0 & GGAACCNTN $_{14} \mathrm{CCACNNA}^{-}$ \\
\hline KP41 & HrpC & 0.0 & GGAACCNAN $_{14}$ CCACNNA $^{-}$ \\
\hline KP43 & HrpK & 0.0 & GGAACCNAN $_{13}$ CCACNNA \\
\hline KP22, KP52 & HopPmaH & $1.0 \mathrm{e}^{-7}$ & GGAACTNTN $_{14}$ CCACNNA $^{-}$ \\
\hline KP24 & AvrPphB & $1.0 \mathrm{e}^{-11}$ & GGAACCNAN $_{13}$ aCACNNA \\
\hline KP61, KP63 & AvrE & $2.0 \mathrm{e}^{-15}$ & $\mathrm{GGAACCN}_{13} \mathrm{CCACNNA}$ \\
\hline KP64 & HrpW & $6.0 \mathrm{e}^{-43}$ & GGAACCNAN $_{13}$ CCACNNA \\
\hline KP54 & None & N/A & GGAACCNcN $_{14}$ CCACNNA \\
\hline
\end{tabular}

\footnotetext{
${ }^{\mathrm{x}}$ Sequences were matched to known proteins using BlastX search engine.

${ }^{y}$ The sequence of each fragment was scanned for candidate HrpL-dependent promoter sequences retaining at least 9 out of 12 conserved bases. Bases in lowercase represent mismatches to the consensus HrpL-dependent promoter sequence (GGAACCNAN ${ }_{14}$ CCACNNA).

${ }^{\mathrm{z}} \mathrm{KP} 1$ was used as a representative of 11 independent but identical sequences.
} 
product exhibited characteristics similar to other type III effectors, including an amphipathic $\mathrm{N}$-terminus, high serine and isoleucine content in the first 50 aa, and few cysteines in the polypeptide (Guttman et al. 2002; Petnicki-Ocweija et al. 2002). Other than an apparent chloroplast localization signal and two deduced transmembrane domains (residues 289 to 307 and 349 to 369) in the carboxy-terminal region of the protein, no other similarities to the deduced ORF54 product were detected in the databases.
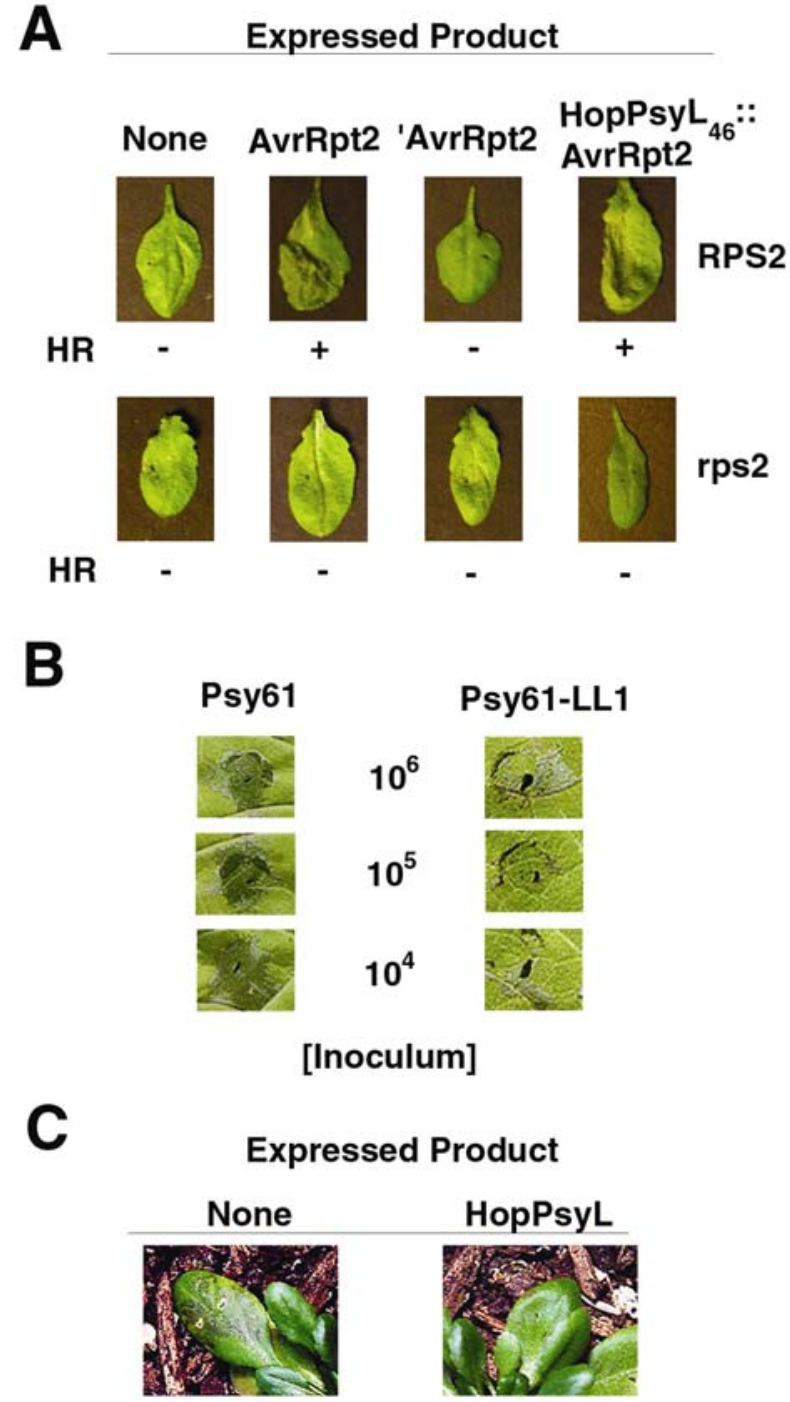

Fig. 1. HopPsyL is a translocated effector with virulence and avirulence functions. A, AvrRpt2 translocation assay. A truncated AvrRpt2 protein (80 to 255 amino acids [aa], 'AvrRpt2) was fused to the N-terminal 46 aa of HopPsyL (HopPsyL ${ }_{46}$ :AvrRpt2). Plasmids expressing the indicated proteins were introduced into DC3000. Arabidopsis Col-0 (RPS2) or rps $2^{-}$leaves were infiltrated with bacterial suspensions at $10^{8} \mathrm{CFU} / \mathrm{ml}$ and evaluated for hypersensitive response (HR) after $18 \mathrm{~h}$. Col-0 leaves showing the HR (+) appear wrinkled. B, Responses of Phaseolus vulgaris cv. Kentucky Wonder to Pseudomonas syringae Psy61 and Psy61-LL. Leaves were inoculated at the indicated concentration and photographed at $36 \mathrm{~h}$. Note the watersoaking lesions observed in tissue inoculated with Psy61 at $10^{5}$ and $10^{4}$ $\mathrm{CFU} / \mathrm{ml}$ that are absent with the same levels of Psy61-LL1. C, Ectopic expression of HopPsyL in DC3000 abolishes symptom development in Arabidopsis thaliana. DC3000 was transformed with plasmids expressing the indicated protein. Bacterial suspensions of $10^{5} \mathrm{CFU} / \mathrm{ml}$ were used to inoculate Arabidopsis Col-0 plants. The photographs were taken at $72 \mathrm{~h}$ after inoculation and were representative of developed symptoms. Note the necrosis and water-soaking symptoms in leaves where no protein was expressed that are absent when HopPsyL was expressed.
To confirm the expression of ORF54, translational fusions between each ORF in the region and ' lac $Z$ were constructed in pMLB1034. Only the fusion to the deduced ORF54 expressed appreciable $\beta$-galactosidase activity in induced SLR400 (pSHL4K) (data not shown). To verify the deduced size of the gene product, an amino-terminal 6xHis fusion to ORF54 was constructed in pQE30. The predicted 40-kDa ORF54 product was detected in immunoblots of DH5 $\alpha$ (pLL54Q30) probed with anti-6xHis antibody (data not shown).

\section{The ORF54 product is translocated into plant cells.}

The structural and genetic features of ORF54 suggested that this protein could be an effector translocated by the hrp TTSS. To test this hypothesis, translational fusions between the amino terminal 46 codons of ORF54 and the carboxy terminus of 'avrRpt2 were created in pDSK519 and tested in the effector translocation assay described previously (Greenberg and Vinatzer 2003; Guttman et al. 2002; Mudgett and Staskawicz 1999). Pto DC3000 (pLL54AvrRpt2K) expressing the fusion elicited a classic hypersensitive response (HR) in $\mathrm{RPS}^{+} A$. thaliana (Fig. 1A). The inoculated tissue of rps 2 plants developed disease symptoms by $42 \mathrm{~h}$ in the form of purple, expanding lesions (data not shown). A null response was detected when these fusions were expressed in the Pto DC3000-A9 ( $h r p A:: \Omega$ ) mutant that is incapable of type III secretion (data not shown). These results are consistent with the TTSS-dependent translocation of the ORF54 product into plant cells and its identification as an effector. The ORF54 product, therefore, was designated as HopPsyL.

\section{hopPsyL is necessary for virulence}

in Phaseolus vulgaris cv. Kentucky Wonder.

To determine the role of HopPsyL in the virulence of Psy61, a hopPsyL::kan insertion was constructed in Psy61 by allelic exchange to create Psy61-LL1. The mutation was confirmed by the increase in size of the fragment amplified by PCR employing primers flanking the insertion site and by Southern hybridization analysis (data not shown). Psy61 recently has been reported to be a pathogen of Phaseolus vulgaris (Deng et al. 2003). P. vulgaris cv. Kentucky Wonder was susceptible to Psy61 infection, as demonstrated by the appearance of watersoaking lesions (symptom score of 4) (Innes et al. 1984) and necrosis observed at all inoculum levels by $36 \mathrm{~h}$ (Fig. 1B, Psy61). A $10^{5}$-fold increase in bacterial populations was detected 3 days postinoculation (Fig. 2). The mutant strain, in contrast, was considerably reduced in virulence. Plants inoculated with Psy61-LL1 showed minimal water-soaking symp-

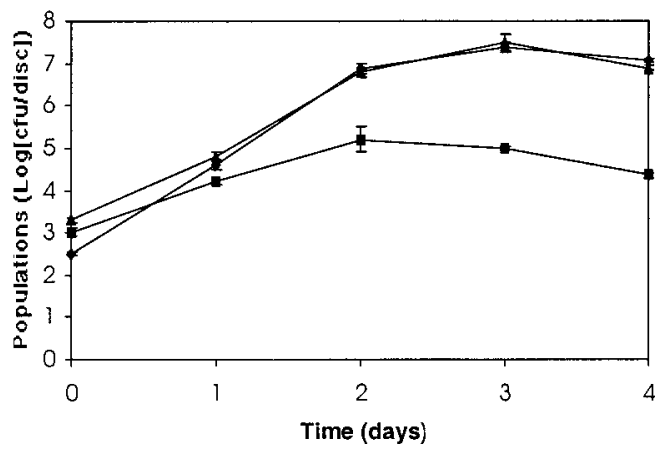

Fig. 2. HopPsyL is required for virulence of Psy61 in Phaseolus vulgaris cv. Kentucky Wonder. Bacterial growth in leaves was monitored over a 4 day period. The bacterial populations were reported as CFU per $38-\mathrm{mm}^{2}$ leaf disk. The values reported are the mean of six replicates. Error bars represent the standard deviation. The experiment was repeated three times with similar results. $\mathbf{A}=$ Psy61 (pLAFR3); $\mathbf{\square}=$ Psy61-LL1 (pLAFR3); = Psy61-LL1 (pLL54L). 
toms (Fig. 1B, Psy61-LL1). Red-brown necrotic response, typical of resistance (Innes et al. 1984), developed near the inoculation site by $36 \mathrm{~h}$ at high inocula (data not shown) and macroscopic symptoms did not develop in tissue inoculated with fewer than $10^{6} \mathrm{CFU} / \mathrm{ml}$ (Fig. 1B, Psy61-LL1). The populations of Psy61-LL1 were $10^{2}$ lower than the parent strain at 3 days (Fig. 2). Complementation of the mutant with a plasmidborne hopPsyL restored virulence to the strain as indicated by the parental population levels detected in tissue (Fig. 2). The failure of the hopPsyL::kan mutant to develop disease symptoms and the reduced growth in the previously susceptible host indicate that HopPsyL is important for Psy61 virulence in this bean cultivar.

\section{HopPsyL acts as an avirulence determinant in $\boldsymbol{A}$. thaliana.}

Ectopic expression of effectors in nonnative strains has been shown previously to affect virulence of the recipient Pseudomonas syringae strains (Staskawicz et al. 1987; Vivian and Gibbon 1997). The region carrying hopPsyL was amplified from Psy61 genomic DNA and cloned into the broad host range cosmid pLAFR3 to create pLL54L. When A. thaliana Col-0 was inoculated with Pto DC3000 (pLL54L) at $10^{5}$ $\mathrm{CFU} / \mathrm{ml}$, an $\mathrm{HR}$ developed by $18 \mathrm{~h}$. A null response was observed at lower inoculum levels (Fig. 1C, HopPsyL). In contrast, leaves inoculated with the virulent Pto DC3000 (pLAFR3) developed typical disease symptoms by $42 \mathrm{~h}$ (Fig. $1 \mathrm{C}$, None). To quantify the effect of HopPsyL on the virulence of Pto DC3000, populations of Pto DC3000 (pLAFR3) and Pto DC3000 (pLL54L) were monitored in inoculated $A$. thaliana Col-0 leaves. Whereas DC3000 (pLAFR3) populations increased $10^{4}$-fold during the 4-day assay period, those of DC3000 (pLL54L) increased only 500-fold (Fig. 3).

\section{HopPsyL does not suppress the HR.}

Several TTSS-dependent effectors of $P$. syringae strains have been identified recently that facilitate pathogenicity of the source strain by an apparent suppression of host defense responses (Abramovitch et al. 2003; Bretz et al. 2003; Espinosa et al. 2003; Tsiamis et al. 2000). HopPsyL, however, does not appear to be suppressing host defense responses. Unlike HopPtoD2, which could delay the timing of the HR during an incompatible host-pathogen interaction (Bretz et al. 2003; Espinosa et al. 2003), HopPsyL did not alter development of the HR elicited by Psy61 in the nonhost plants Nicotiana tabacum cv. Samsun, Phaseolus lunatus cv. Roma, and A. thaliana ecotypes Col-0, Leesburg, Dijon, Ws, Shadhana, and Col-0/rps $2^{-}$. When suspensions $\left(10^{8} \mathrm{CFU} / \mathrm{ml}\right)$ of Psy61 or

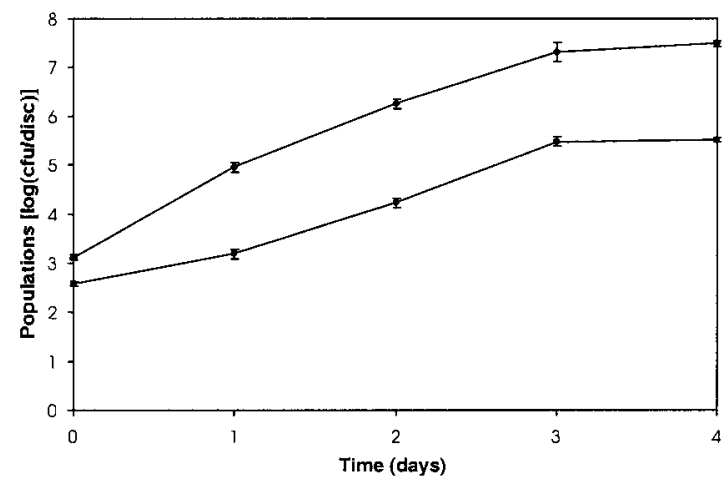

Fig. 3. Ectopic expression of HopPsyL reduces the virulence of DC 3000 in Arabidopsis thaliana Col-0. Bacterial populations in leaves were monitored and reported as CFU per $38-\mathrm{mm}^{2}$ leaf disk. The values reported are the mean of six replicates. Error bars represent the standard deviation. The experiment was repeated three times with similar results. DC3000 (pLAFR3); = DC3000 (pLL54L).
Psy61-LL1 were inoculated into leaf tissue of the mentioned plants, no differences in development or phenotype of the HR elicited were detected during the initial $16 \mathrm{~h}$ of the interaction (data not shown). The earliest symptoms (e.g., water soaking visible on the abaxial leaf surface) were detected at the same time in all cases. In contrast to HopPtoD2, (Bretz et al. 2003), HopPsyL had no effect on the expression of an A. thaliana Col-0 chromosomal PR-1:GUS fusion. Similar levels of GUS activity were observed in tissue inoculated with Psy61, Psy61LL1, DC3000 (pLAFR3), or DC3000 (pLL54L) at $10^{6}$ $\mathrm{CFU} / \mathrm{ml}$ (data not shown).

It was possible that the activity of HopPsyL was limited to cells of Kentucky Wonder. If so, an effect of HopPsyL expression on the incompatible response of Kentucky Wonder to DC3000 would be predicted. When suspensions $\left(10^{8} \mathrm{CFU} / \mathrm{ml}\right)$ of DC3000 (pLAFR3) or DC3000 (pLL54L) were infiltrated into P. vulgaris cv. Kentucky Wonder leaves, the onset of the induced HR were indistinguishable between the two strains. Taken together, these results suggest that HopPsyL does not suppress plant defense responses, but instead acts by another mechanism to facilitate parasitism of Kentucky Wonder by Psy61.

\section{Distribution of hopPsyL among Pseudomonas syringae strains.}

To determine the distribution of hopPsyL alleles among Pseudomonas syringae strains, a PCR screen was performed using the primers 54-549 and 54-1247. Diagnostic fragments indicative of the presence of hopPsyL were amplified from 6 of 10 P. syringae pv. syringae strains tested (Table 2), but not from any of the $P$. syringae pvs. tomato, maculicola, or phaseolicola strains screened. Sequence of the amplified fragments

Table 2. Conservation of hopPsyL among Pseudomonas syringae strains

\begin{tabular}{lccl}
\hline & \multicolumn{2}{c}{ Detection by } & \\
\cline { 2 - 4 } Strain $^{\mathbf{w}}$ & PCR $^{\mathbf{x}}$ & Hybridization $^{\mathbf{y}}$ & Response $^{\mathbf{z}}$ \\
\hline P. syringae & & & \\
61 & + & + & $\mathrm{D}$ \\
B3A & + & + & $\mathrm{D}$ \\
B76 & + & + & Null \\
5D417 & + & + & Null \\
B362 & + & + & $\mathrm{d}$ \\
B382 & + & + & Null \\
3097 & + & + & Null \\
Ps-1 Bean & - & - & na \\
B460 & - & - & na \\
Ps-1 & - & - & na \\
1053 & - & - & na \\
WYN 108 & - & - & na \\
S-4B-1 & - & - & na \\
Escherichia coli & & - & na \\
DH5 & - & - & .
\end{tabular}

${ }^{\mathrm{w}}$ Strains (Denny et al. 1988) were inoculated at $10^{7} \mathrm{CFU} / \mathrm{ml}$. Negative results were obtained for $P$. syringae pv. maculicola \#1, \#5, and \#10; $P$. syringae pv. phaseolicola NK343, B130, and BK378; and $P$. syringae pv. tomato $\mathrm{T} 1,4355,3523, \mathrm{~B} 76, \mathrm{~B} 88, \mathrm{~B} 118, \mathrm{~B} 121, \mathrm{~B} 122, \mathrm{~B} 19$, and DC3000.

${ }^{\mathrm{x}}$ Polymerase chain reaction (PCR) analysis was performed using primers 54-549 and 54-1247 and an annealing temperature of $55^{\circ} \mathrm{C}$. A positive sign indicates specific amplification of a 700-bp fragment. Psy61 was used as a positive control, and DH5 $\alpha$ as a negative control.

${ }^{\mathrm{y}}$ Hybridization experiments were performed using a 698-bp probe generated using primers 54-549 and 54-1247 and room temperature washes in $1 \times \mathrm{SSC}(0.15 \mathrm{M} \mathrm{NaCl}$ plus $0.015 \mathrm{M}$ sodium citrate). A positive sign indicates that hybridization of the probe could be detected in autoradiograms.

${ }^{\mathrm{z}}$ Plant responses in Kentucky Wonder within $120 \mathrm{~h}$ after inoculation. D = Slowly developing necrosis typical of disease observed at $36 \mathrm{~h}$; d = slight symptoms of disease by $72 \mathrm{~h}$; Null = no response detected during the 5-day assay period; na = not tested. 
exhibited greater than $99 \%$ identity with the Psy61 hopPsyL (data not shown). To screen for more divergent alleles, the 698bp fragment carrying the amino terminal portion of hopPsyL was amplified from Psy61 genomic DNA and used to probe the genomes of the selected strains for presence of an hopPsyL allele by low stringency hybridization. Hybridization results mirrored those from the PCR screen. Those strains that produced the indicative PCR product hybridized to the probe whereas the other strains did not. An ortholog of hopPsyL was not detected in the DC3000 and B728A genomes. Of the strains carrying HopPsyL, only B632, originally isolated from diseased beans (J. DeVey, personal communication) and B3A, isolated from a peach variety, were apparent pathogens of Kentucky Wonder (Table 2). The contribution of HopPsyL to this virulence has not been established. The observation that only a few strains carrying a hopPsyL allele are pathogens of bean suggests that HopPsyL does not act epistatically to other effectors to control virulence in the host plant.

\section{DISCUSSION}

The pathogenicity and host range of $P$. syringae strains have been linked to the expression of strain-specific arrays of effectors that are translocated into host cells by the hrp TTSS. By utilizing the previous observations that all known effectors expressed by $P$. syringae strains are components of the hrp regulon (Fouts et al. 2002; Xiao and Hutcheson 1994; Zwiesler-Vollick et al. 2002) and, therefore, are dependent upon HrpL for transcription, an E. coli-based HrpL-dependent promoter-trap screen was developed to identify candidate effector genes expressed by a strain. The screen was successful in identifying several effectors previously characterized in other strains. For example, avrE originally was isolated from a $P$. syringae pv. tomato strain (Lorang and Keen 1995) and is thought to be a component of the conserved effector locus present in all $P$. syringae strains (Alfano et al. 2000). avrPphB from $P$. syringae pv. phaseolicola has been shown to be a cysteine protease with avirulence activities on bean plants (Shao et al. 2002). hopPmaH encodes a secreted pectin lyase-like effector initially identified in a $P$. syringae pv. maculicola strain and is conserved in many $P$. syringae strains, including Psy61 (Guttman et al. 2002). Although orthologs of these semiconserved effectors were identified in Psy61, each carried amino acid substitutions that could affect their activity, as was observed for AvrPphE alleles (Stevens et al. 1998).

Of primary interest in this study was the promoter-active fragment KP54. This fragment carried a near-consensus HrpLdependent promoter but the associated coding sequence lacked similarity to other genes. HrpL-dependent activity of the fragment was verified in Psy61 and the ORF identified directly downstream of the HrpL-dependent promoter was shown to encode HopPsyL, a 40.5-kDa protein with no homologs in the databases. HopPsyL was translocated into host cells by the $h r p$ TTSS and facilitated Psy61 virulence in Phaseolus vulgaris cv. Kentucky Wonder. When ectopically expressed in the $A$. thaliana pathogen DC3000, HopPsyL acted as an avirulence determinant, reducing the growth of the expressing strain and suppressing symptom development.

The mechanisms through which HopPsyL contributes to parasitism and disease in Kentucky Wonder remain unknown. No enzymatic or metabolic function could be assigned to HopPsyL, but the structural features suggest that it may localize to chloroplasts as proposed for several other effectors of Pseudomonas syringae strains (Greenberg and Vinatzer 2003; Guttman et al. 2002). In contrast to several recently characterized effectors, HopPsyL does not appear to be a general suppressor of plant defense responses. For instance, expression of the locus in the native Psy61 or in Pto DC3000 did not affect the ability of the strain to elicit the HR or related responses in resistant plants. HopPsyL does not appear to act epistatically to other effectors to facilitate pathogenesis. Namely, ectopic expression of hopPsyL in Pto DC3000 did not expand its host range to include Kentucky Wonder, and most strains of $P$. syringae that carry a homolog of hopPsyL were not pathogens of Kentucky Wonder. One explanation for the role of HopPsyL in pathogenicity could be that it acts as a virulence gene required for Psy61 to replicate in Kentucky Wonder. Alternatively, HopPsyL could act to mask the activity of another $a v r$ product specifically active in Kentucky Wonder, similarly to the suppression of AvrPphF activity in Canadian Wonder by AvrPphC (Tsiamis et al. 2000). Consistent with this latter hypothesis, inactivation of hopPsyL in Psy61 resulted in an apparent conversion to an incompatible interaction in Kentucky Wonder. Irrespective of the mechanism of action, HopPsyL can be added to a growing set of $P$. syringae effectors that are required for virulence in one host but elicit defense responses in another host.

In summary, the HrpL-dependent promoter-trap screen provides a relatively inexpensive, high throughput assay for candidate HrpL-dependent promoters that is independent of the role of the gene product in pathogenesis, and can be used to survey previously uncharacterized $P$. syringae strains for effector genes. The ability to identify the set of effectors produced by a strain should facilitate comparative analyses of $P$. syringae strains to identify the factors controlling pathogenicity and host range. By applying this screen to Psy61, we were able to isolate five effectors, including a novel locus required for virulence of the source strain, but the survey of the Psy61 genome is far from complete. P. syringae strains are predicted to express up to 50 effectors (Greenberg and Vinatzer 2003). In DC3000, a trial promoter-trap screen led to the identification of a translocated protein, tyrosine phosphatase, that modulates several defense responses (Bretz et al. 2003) and sequences obtained during the characterization of the promoter-active fragment carrying the $s h c A$ promoter facilitated characterization of the exchangeable effector loci carried by 30 P. syringae strains (Charity et al. 2003). Thus, the conservation of hrpL among $P$. syringae strains (Sawada et al. 1999) indicates that this assay should be broadly applicable to all $P$. syringae strains.

\section{MATERIALS AND METHODS}

\section{Bacterial stains and media.}

Strains and plasmids used in this study are described in Table 3. Bacteria were grown routinely on KB agar (Atlas 1993). Plasmids were propagated in E. coli DH5 . E. coli strains were grown at $37^{\circ} \mathrm{C}$, and $P$. syringae strains were grown at $25^{\circ} \mathrm{C}$. Luria broth, MacConkey, and M63 minimal salts media were used for culture of E. coli strains (Atlas 1993). M63 medium was supplemented with $1 \mathrm{mM} \mathrm{MgSO}_{4}$ and $1 \%$ fructose. The following antibiotics were added at the indicated concentrations: ampicillin, $200 \mu \mathrm{g} / \mathrm{ml}$; kanamycin, $50 \mu \mathrm{g} / \mathrm{ml}$; spectinomycin, $100 \mu \mathrm{g} / \mathrm{ml}$, tetracycline, $25 \mu \mathrm{g} / \mathrm{ml}$; nalidixic acid, $50 \mu \mathrm{g} / \mathrm{ml}$; rifampicin, $200 \mu \mathrm{g} / \mathrm{ml}$; and chloramphenicol; $30 \mu \mathrm{g} / \mathrm{ml}$. L-arabinose concentration in agar media was $0.01 \%$, unless stated otherwise.

\section{General DNA manipulations.}

Restriction enzymes were purchased from Invitrogen (Bethesda, MD, U.S.A.). T4 DNA ligase was acquired from New England Biolabs (Beverly, MA, U.S.A.) and used according to the manufacturer's recommendations. Basic 
manipulations were done using standard procedures (Sambrook and Russell 2001). PCRs were performed using a Hybaid PCR Sprint thermal cycler (ThermoElectron Corp., Waltham, MA, U.S.A.) with 50- $\mu$ l reaction volumes. Unless indicated otherwise, Pwo polymerase (Roche Molecular Biochemicals, Mumbai, India) was used to amplify fragments for cloning.

\section{Construction of genomic library.}

Genomic DNA isolations were performed following the cetyltrimethylammonium bromide protocol (Sambrook and Russell 2001), and DNA concentration was adjusted to 1.5 $\mu \mathrm{g} / \mu \mathrm{l}$. Genomic DNA (30 to $40 \mu \mathrm{g}$ ) was digested with 1 unit of Sau3A for $2,5,10,15$, and $30 \mathrm{~min}$ at $37^{\circ} \mathrm{C}$. Partially digested DNA was fractionated by agarose gel electrophoresis, and fragments of desired sizes were isolated from gels using the Prep-A-Gene kit (Bio-Rad, Hercules, CA, U.S.A.). Isolated fragments were ligated to BamHI digested pRG970 at a molar ratio of 5:1 using T4 DNA ligase at $4^{\circ} \mathrm{C}$.

\section{HrpL-dependent promoter-trap screen.}

E. coli SLR400 (pSHL4K) was transformed by electroporation with the genomic libraries constructed as described above and transformants screened for Lac phenotype on MacConkey lactose media supplemented with $0.01 \%$ (wt/vol) arabinose. Colonies exhibiting any level of a Lac-positive phenotype were single-colony purified on $\mathrm{KB}$ medium. Isolates then were streaked on MacConkey lactose medium with or without $0.01 \%$ (wt/vol) arabinose and Lac phenotype scored at $18 \mathrm{~h}$. Plasmids from colonies exhibiting Ara-dependent Lac phenotype were isolated and nucleotide sequence obtained using primers 970-5 and 970-3 flanking the insert site.

\section{$\beta$-galactosidase assays.}

$\beta$-galactosidase activity in bacterial cells was estimated by the procedures of Miller (Miller 1971).

\section{Inverse PCR.}

Inverse PCR was performed using the procedures of Ochman and associates (1990). Psy61 genomic DNA $(1 \mu \mathrm{g})$ was digested with SstI and self ligated. The ligation mixture was diluted $100 \times$ and used as template for PCR using primers 54-739B and 54-1029 and ProofPro DNA polymerase (Continental Lab Products, San Diego, CA, U.S.A.) following the manufacturer's protocol. These primers were located 100 to $200 \mathrm{bp}$ internal to the previously sequenced portion of ORF54, such that any specific amplification product could be identified by the presence of these known flanking sequences. Thermal cycling was carried out using a $53^{\circ} \mathrm{C}$ annealing temperature and an extension time of $6 \mathrm{~min}$. Amplified fragments were gel purified and nucleotide sequence obtained at the University of Maryland Sequencing facility.

Table 3. Strains, plasmids, and primers used in this study

\begin{tabular}{|c|c|c|}
\hline Strain or plasmid & Genotype or phenotype & Reference or source \\
\hline \multicolumn{3}{|l|}{ Strain } \\
\hline \multicolumn{3}{|l|}{ Escherichia coli } \\
\hline DH5 $\alpha$ & endA1 hsdR17 $\left(\mathrm{r}_{\mathrm{k}}^{-} \mathrm{m}_{\mathrm{k}}^{-}\right)$supE44 thi-1 recA1 gyrA96 relA1 · $(\arg R$-lacZYA) U169 $\$ 80$ lacZDM15 & Invitrogen \\
\hline MC4100 & F' araD139 $\cdot($ argF-lacZYA) U169 rpsL150 relA1 flb-5301 ptsF 25 deoC1 & Casadaban 1976 \\
\hline SLR400 & araD139 (ara leu) 7697 derivative of MC4100 & S. Benson \\
\hline \multicolumn{3}{|c|}{ Pseudomonas syringae } \\
\hline A9 & hrpA mutant, $\mathrm{HR}^{-}, \mathrm{Rif}^{\mathrm{T}}, \mathrm{Kan}^{\mathrm{r}}$ & Wei et al. 2000 \\
\hline DC3000 & Wild-type, $\mathrm{Rif}^{\mathrm{T}}, \mathrm{HR}^{+}$tomato and Arabidopsis pathogen & Cuppels 1986 \\
\hline Psy61 & Wild-type, $\mathrm{Nal}^{\mathrm{r}}, \mathrm{HR}^{+}$bean pathogen & Baker et al. 1987; Deng et al. 2003 \\
\hline Psy61-2070 & hopPsyA::TnphoA, $\mathrm{Nal}^{\mathrm{r}}, \mathrm{Kan}^{\mathrm{r}}$ & Huang et al. 1991 \\
\hline Psy61-2074 & $h r p L:: \operatorname{Tn} p h o A, \mathrm{Nal}^{\mathrm{r}}, \mathrm{Kan}^{\mathrm{r}}$ & Huang et al. 1991 \\
\hline Psy61-LL1 & hopPsyL::pUC18K, $\mathrm{Nal}^{\mathrm{r}} \mathrm{Kan}^{\mathrm{r}}$ & This work \\
\hline \multicolumn{3}{|l|}{ Plasmids } \\
\hline PDSK519 & Broad-host range vector, IncQ Kan ${ }^{\mathrm{r}}$ & Keen et al. 1988 \\
\hline pJBAvrRpt2-600 & avrRpt 2 cloned into pDSK600 & Bretz et al. 2003 \\
\hline pLAFR3 & IncP1, Tet ${ }^{r}$ & Staskawicz et al. 1987 \\
\hline pLL54L & 1.3-kb polymerase chain reaction (PCR) product containing hopPsyL cloned into pLAFR3 & This work \\
\hline $\mathrm{pLL} 4_{46-170} \mathrm{~K}$ & $0.5-\mathrm{kb}$ PCR product containing codons 46 to 146 of hopPsyL cloned into pUC18K & This work \\
\hline pLL54AvrRpt2K & & This work \\
\hline pLL54 $46:$ AvrRpt $2 \mathrm{~K}$ & N-terminal 46 codons of hopPsyL fused to 'avrRpt2 in pDSK519 & This work \\
\hline pLL54Q30 & 1.2-kb PCR product containing ORF54 cloned into pQE30 & This work \\
\hline pMLB1034 & 'lacZYA, for creating translational fusions, $\mathrm{Amp}^{\mathrm{r}}$ & Silhavy et al. 1984 \\
\hline pMPM-K6 & $\mathrm{AraC}^{+}, \mathrm{P}_{\mathrm{bad}}-\mathrm{MCS}, \mathrm{Kan}^{\mathrm{r}}, \mathrm{Sp}^{\mathrm{r}}: \Omega, \operatorname{OriV}_{\mathrm{P} 15 \mathrm{~A}}$ & Mayer 1995 \\
\hline pQE30 & $\mathrm{Am}^{\mathrm{r}}$, mes:his & Qiagen \\
\hline pRG970 & IncP, $\mathrm{Sp}^{\mathrm{r}}$, promotorless lac $Z$ and gusA in opposite orientations & Van den Eede et al. 1992 \\
\hline pSHL $4 \mathrm{~K}$ & $\mathrm{P}_{\mathrm{BAD}}:^{\prime} h r p L$ fusion in pMPM-K6, $\mathrm{Km}^{\mathrm{r}}, \Delta \Omega: \mathrm{Sp}^{\mathrm{r}}$ & Bretz et al. 2003 \\
\hline pTS54R & 1.2-kb genomic fragment from Pss61 cloned into pRG970 & This work \\
\hline pUC18K & aphA3 cassette cloned into $S m a \mathrm{I}$ site of pUC18 & Menard et al. 1993 \\
\hline Primers & & $\ldots$ \\
\hline $54-549 \mathrm{E}$ & GGAATTCGGCAACGCATGATTGAG & $\ldots$ \\
\hline 54-1247B & CGGGATCCAGCGATCTGCCGTTGTCCA & $\ldots$ \\
\hline $54-739 \mathrm{E}$ & GGAATTCGTCGCGACAGCAAGGCCGTA & $\ldots$ \\
\hline 54-739B & CGGGATCCTACGGCCTTGCGTCGCGAC & $\ldots$ \\
\hline $54-1098$ & AACACCTTGCCTTCAAGAGA & $\ldots$ \\
\hline 54-1029 & GCTCAGGGGCGGTGTCAATG & $\ldots$ \\
\hline $54-549 \mathrm{X}$ & GCTCTAGAGGCAACGCATGATTGAG & $\ldots$ \\
\hline $54 \mathrm{q} 30 \mathrm{~S}$ & TCCCCCGGGAACCCCATTCGTAATTCT & $\ldots$ \\
\hline $54-1871 \mathrm{~S}$ & ACGCGTTTGCCGAAAATGCCTGTAT & $\ldots$ \\
\hline $54-\mathrm{Rpt}_{46}-\mathrm{SapI}$ & GATGCTCTTCACCCTACGGCCTTGCTGTCGCG & $\ldots$ \\
\hline AvrRpt $2_{408}$ SapI & GATGCTCTTCAGGGAAGCACGAGACGGGCGGT & $\ldots$ \\
\hline AvrRpt2-1028X & GCTCTAGATAGGGACCAAAAAGCCAGAC & $\ldots$ \\
\hline $970-5$ & CCACAGCCGTCGGAGT & $\ldots$ \\
\hline $970-3$ & ACGCCAGGGTTTTCCCAGTCA & $\ldots$ \\
\hline
\end{tabular}




\section{TAIL-PCR.}

The Psy61 genome was used as template for TAIL-PCR following the protocols of Liu and Whittier (1995). Primer 54$549 \mathrm{E}$ was used for the primary PCR reaction with the degenerate primer AD3. For the secondary and tertiary nested PCR reactions, primers 54-739E and 54-1029 were used, respectively. The PCR product was purified using Qiaquick PCR purification kit (Qiagen, Valencia, CA, U.S.A.) and nucleotide sequence obtained at the University of Maryland sequencing facility.

\section{Construction of Psy61-LL1.}

The region of hopPsyL corresponding to codons 40 to 170 was amplified by PCR from genomic Psy61 DNA using primers 54-739E and 54-1247B, digested with EcoRI and BamHI, and ligated into pUC18K, which does not replicate in Psy61. The resulting plasmid was transformed into Psy61. Nal ${ }^{\mathrm{r}} \mathrm{Kan}^{\mathrm{r}}$ integrants were selected and gene disruption confirmed by PCR analysis and Southern hybridization.

\section{Construction of pLL54Q30 and size determination of HopPsyL.}

hopPsyL was amplified using primers 54q30S and 54$1871 S$, and cloned into pQE30 as a SmaI fragment. To determine the size of HopPsyL, DH5 $\alpha$ (pLL54Q30) was grown to an optical density at $600 \mathrm{~nm}$ of 0.2 , IPTG was added to $2 \mathrm{mM}$, and HopPsyL expression was induced for $2 \mathrm{~h}$. The cells were harvested and resuspended in $50 \mu \mathrm{l}$ of sodium dodecyl sulfate (SDS)-loading buffer. Samples were run on a $12 \%$ SDS-polyacrylamide gel electrophoresis gel, and blotted onto polyvinylidene diflouride membranes. The samples were probed using a monoclonal anti-His antibody (Novagen, Madison, WI, U.S.A.), and visualized using a goat anti-mouse HRP conjugate and an ECL chemiluminescence kit (Amersham-Pharmacia, Piscataway NJ, U.S.A.).

\section{AvrRpt 2 translocation assay.}

AvrRpt 2 translocation assays were performed as described previously (Guttman et al. 2002), with minor changes. The amino terminal region of hopPsyL was amplified from genomic Psy61 DNA using primer 54-549 and reverse primer 54-Rpt $2_{46}$-SapI to generate a fragment carrying the first 46 codons of hopPsyL. 'avrRpt2 was amplified using primers AvrRpt2-408SapI and AvrRpt2-1028X. These fragments were digested with SapI and ligated. The ligation mixture was used as a template for a PCR amplification of the fusion using primers 54-549X and AvrRpt2-1028X. The resulting PCR product was extracted from agarose gels using the QIAspin kit (Qiagen) and cloned into pDSK519 as an XbaI fragment. Clones with the correct orientation were transformed into DC3000 and transformants screened for phenotype in wildtype or rps 2 A. thaliana leaves.

\section{Virulence assays.}

A. thaliana Col-0 and Phaseolus vulgaris cv. Kentucky Wonder plants were inoculated with suspensions of the indicated strains at $10^{5} \mathrm{CFU} / \mathrm{ml}$ unless reported otherwise. $P$. vulgaris cv. Kentucky Wonder plants were scored daily using the five-point scale described previously (Innes et al. 1984). Bacterial populations were monitored as described previously (Bertoni and Mills 1987). For HR phenotype in $N$. tabacum, A. thaliana, or P. lunatus leaves, bacteria were grown to $10^{9} \mathrm{CFU} / \mathrm{ml}$ in $\mathrm{KB}$ and serially diluted to $10^{8}, 10^{7}$, and $10^{6}$. Dilutions were infiltrated into leaves and HR was scored after $18 \mathrm{~h}$. The plants used were: N. tabacum cv. Samsun, P. lunatus cv. Roma, and A. thaliana accessions Col-0, Col-0/rps2, Tsu-1, Leesburg, Shadhana, Ws, and Dijon.
PR1 induction assay.

Leaves of $A$. thaliana Col0:PR1/GUS plants (Shapiro and Zhang 2001) were inoculated with bacterial suspensions $\left(10^{6}\right.$ $\mathrm{CFU} / \mathrm{ml}$ ). After $48 \mathrm{~h}$, single-leaf disks were excised and used for GUS assay with the fluorogenic substrate 4-methyl-umberlliferyl- $\beta$-D-glucuronide (ICN Biomedicals, Costa Mesa, CA, U.S.A.). Reactions were incubated for $30 \mathrm{~min}$ at $37^{\circ} \mathrm{C}$, and the fluorescence was measured using a TKO 100 fluorometer (Amersham Pharmacia Biotech, Piscataway, NJ, U.S.A.). The units of activity were calculated using a standard curve.

\section{Colony hybridizations.}

A ${ }^{32}$ P-labeled probe was generated by PCR amplification from Psy61 genomic DNA with primers 54-549E and 54$1247 \mathrm{~B}$ in a reaction containing $25 \mu \mathrm{Ci}$ of $\gamma_{-}{ }^{32} \mathrm{P}$ dATP. Pseudomonas syringae colonies were transferred to charged nylon membranes, lysed, and allowed to hybridize to the labeled probe under low stringency conditions (Sambrook and Russell 2001). Colonies that hybridized to the probe were visualized by autoradiography.

\section{ACKNOWLEDGMENTS}

This work was supported by grants MCB 9729524 and MCB0215417 from the National Science Foundation and by grants to K. Pak and S. Zeyad from the Howard Hughes Medical Institute Undergraduate Biological Sciences Education Program. We thank M. Howard and J. Bretz for their helpful comments on the manuscript.

\section{LITERATURE CITED}

Abramovitch, R., Kim, Y.-J., Chen, S., Dickman, M., and Martin, G. 2003. Pseudomonas type III effector AvrPtoB induces plant disease susceptibility by inhibition of host programmed cell death. EMBO (Eur. Mol. Biol. Organ.) J. 22:60-69.

Alfano, J. R., Charkowski, A. O., Deng, W.-L., Badel, J. L., PetnickiOcwieja, T., van Dijk, K., and Collmer, A. 2000. The Pseudomonas syringae Hrp pathogenicity island has a tripartite mosaic structure composed of a cluster of type III secretion genes bound by exchangeable effector and conserved effector loci that contribute to parasitic fitness and pathogenicity in plants. Proc. Natl. Acad. Sci. U.S.A. 97:4856-4861.

Arnold, D., Gibbon, M., Jackson, R., Wood, J., Brown, J., Mansfield, J., Taylor, J., and Vivian, A. 2001. Molecular characterization of avrPphD, a widely distributed gene from Pseudomonas syringae pv. phaseolicola involved in non-host recognition by pea (Pisum sativum). Physiol. Mol. Plant Pathol. 58:55-62.

Atlas, R. M. 1993. Handbook of Microbiological Media. CRC Press, Boca Raton, FL, U.S.A.

Baker, C. J., Atkinson, M. M., and Collmer, A. 1987. Concurrent loss in Tn5 mutants of the ability to induce the HR and host plasma membrane $\mathrm{K}^{+} / \mathrm{H}^{+}$exchange in tobacco. Phytopathology 77:1268-1272.

Bertoni, G., and Mills, D. 1987. A simple method to monitor growth of bacterial populations in leaf tissue. Phytopathology 77: 832-835.

Bretz, J., Mock, N., Charity, J., Zeyad, S., Baker, C., and Hutcheson, S. 2003. A translocated protein tyrosine phosphatase of Pseudomonas syringae pv. tomato DC3000 modulates plant defence response to infection. Mol. Microbiol. 49:389-400.

Casadaban, M. J. 1976. Transposition and fusion of the lac genes to selected promoters in Escherichia coli using bacteriophage lambda and Mu. J. Mol. Biol. 104:541-555.

Charity, J., Pak, K., and Hutcheson, S. 2003. Novel exchangeable effector loci associated with the hrp pathogenicity island of $P$. syringae: Evidence for integron-like assembly from transposed gene cassettes. Mol. Plant-Microbe Interact. 16:495-507.

Chen, Z., Kloek, A. P., Boch, J., Katagiri, F., and Kunkel, B. N. 2000. The Pseudomonas syringae avrRpt2 gene product promotes pathogen virulence from inside plant cells. Mol. Plant-Microbe Interact. 13:1312-1321.

Collmer, A., Lindegerg, M., Petnicki-Ocwieja, T., Schneider, D., and Alfano, J. 2002. Genomic mining type III secretion system effectors in Pseudomonas syringae yields new picks for all TTSS prospectors. Trends Microbiol. 10:462-469.

Cornelis, G., and VanGijsegem, F. 2000. Assembly and function of type III secretory systems. Annu. Rev. Microbiol. 54:735-774. 
Cuppels, D. A. 1986. Generation and characterization of Tn5 insertion mutations in Pseudomonas syringae pv. tomato. Appl. Environ. Microbiol. 51:323-327.

Dangl, J., and Jones, J. 2001. Plant pathogens and integrated defence responses to infection. Nature (Lond.) 411:826-833.

Deng, W. L., Rehm, A., Charkowski, A., Rojas, C., and Collmer, A. 2003. Pseudomonas syringae exchangeable effector loci: sequence diversity in representative pathovars and virulence function in $P$. syringae pv. syringae B728a. J. Bacteriol. 185:2592-2602.

Denny, T., Gilmour, M., and Selander, R. 1988. Genetic diversity and relationships of two pathovars of Pseudomonas syringae. J. Gen. Microbiol. 134:1949-1960.

Espinosa, A., Guo, M., Tam, V., Fu, Z., and Alfano, J. 2003. The Pseudomonas syringae type III-secreted protein HopPtoD2 possesses protein tyrosine phosphatase activity and suppresses programmed cell death in plants. Mol. Microbiol. 49:377-387.

Fouts, D., Abramovitch, R., Alfano, J., Baldo, A., Buell, C., Cartinhour, S., Chatterjee, A., D’Ascenzo, M., Gwinn, M., Lazarowitz, S., Lin, N.-C., Martin, G., Rehm, A., Schneider, D., vanDijk, K., Tang, X., and Collmer, A. 2002. Genomewide identification of Pseudomonas syringae pv. tomato DC3000 promoters controlled by the HrpL alternative sigma factor. Proc. Natl. Acad. Sci. U.S.A. 99:2275-2280.

Gopalan, S., Bauer, D. W., Alfano, J. R., Loniello, A. O., He, S. Y., and Collmer, A. 1996. Expression of the Pseudomonas syringae avirulence protein AvrB in plant cells alleviates its dependence on the hypersensitive response and pathogenicity (Hrp) secretion system in eliciting genotype-specific hypersensitive cell death. Plant Cell 8:1095-1105.

Greenberg, J., and Vinatzer, B. 2003. Identifying type III effectors of plant pathogens and analyzing their interaction with plant cells. Curr. Opin. Microbiol. 6:20-28.

Guttman, D., Vinatzer, B., Sarkar, S., Ranall, M., Kettler, G., and Greenberg, J. 2002. A functional screen for the type III secretome of the plant pathogen Pseudomonas syringae. Science 295:1722-1726.

Huang, H. C., Hutcheson, S. W., and Collmer, A., 1991. Characterization of the hrp cluster from Pseudomonas syringae pv. syringae 61 and TnphoA tagging of exported or membrane-spanning Hrp proteins. Mol Plant-Microbe Interact. 4:469-476.

Hutcheson, S. 2001. The molecular biology of hypersensitivity to plant pathogenic bacteria. J. Plant Pathol. 83:151-172.

Hutcheson, S. W. 1999. The hrp cluster of Pseudomonas syringae: a pathogenicity island encoding a type III protein translocation complex? Pages 309-329 in: Pathogenicity Islands and Other Mobile Virulence Elements. J. B. Kaper and J. Harker, eds. American Society of Microbiology, Washington, D.C.

Hutcheson, S. W., Bretz, J., Sussan, T., Jin, S., and Pak, K. 2001. The enhancer binding protein HrpR and HrpS interact to regulate hrp-encoded type III protein secretion in Pseudomonas syringae strains. J. Bacteriol. 183:5589-5598

Innes, N., Conway, J., and Taylor, J. 1984. Resistance to halo-blight in the Cambridge accessions V4604 and V4058 of Phaseolus beans. Ann. Appl. Biol. 104:307-314.

Jackson, R. W., Athanassopoulos, E., Tsiamis, G., Mansfield, J. W., Sema, A., Arnold, D. L., Gibbon, M. J., Murillo, J., Taylor, J. D., and Vivian, A. 1999. Identification of a pathogenicity island, which contains genes for virulence and avirulence, on a large native plasmid in the bean pathogen Pseudomonas syringae pv. phaseolicola. Proc. Natl. Acad. Sci. U.S.A. 96:10875-10880.

Keen, N., Tamaki, J., Kobayashi, D., and Trollinger, D. 1988. Improved broad host range plasmids for DNA cloning in gram negative bacteria. Gene 70:191-197.

Kim, J. F., Charkowski, A. O., Alfano, J. R., Collmer, A., and Beer, S. V. 1998. Sequences related to transposable elements and bacteriophages flank avirulence genes of Pseudomonas syringae. Mol. Plant-Microbe Interact. 11:1247-1252.

Leach, J. E., and White, F. F. 1996. Bacterial avirulence genes. Annu. Rev. Phytopathol. 34:153-179.

Lee, J., Klusener, B., Tsiamis, G., Stevens, C., Neyt, C., Tampakaki, A. P., Panopoulos, N. J., Noller, J., Weiler, E., Cornelis, G. R., Mansfield, J.

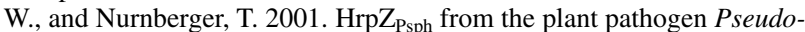
monas syringae pv. phaseolicola binds to lipid bilayers and forms an ion-conducting pore in vitro. Proc. Natl. Acad. Sci. U.S.A. 98:289-294.

Leister, R. T., Ausubel, F. M., and Katagiri, F. 1996. Molecular recognition of pathogen attack occurs inside of plant cells in plant disease resistance specified by the Arabidopsis genes RPS 2 and RPM1. Proc. Natl. Acad. Sci. U.S.A. 93:3459-3464.

Lindgren, P. B., Peet, R. C., and Panopoulos, N. J. 1986. Gene cluster of Pseudomonas syringae pv. phaseolicola controls pathogenicity on bean plants and hypersensitivity on nonhost plants. J. Bacteriol. 168:512-522.

Liu, Y., and Whittier, R. 1995. Thermal asymmetric interlaced PCR: Automatable amplification and sequencing of insert end fragments from P1 and YAC clones for chromosome walking. Genomics 25:674-681.

Lorang, J. M., and Keen, N. T. 1995. Characterization of avrE from Pseudomonas syringae pv. tomato: a hrp-linked avirulence locus consisting of at least two transcriptional units. Mol. Plant-Microbe Interact. 8:4957

Mackey, D., Holt, B., Wiig, A., and Dangl, J. 2002. RIN4 interacts with Pseudomonas syringae type III effector molecules and is required for RPM1-mediated resistance in Arabidopsis. Cell 108:743-754.

Mayer, M. P. 1995. A new set of useful cloning and expression vectors derived from pBluescript. Gene 163:41-46.

Menard, R., Sansonetti, P. J., and Parsot, C. 1993. Nonpolar mutagenesis of the ipa genes defines IpaB, IpaC, and IpaD as effectors of Shigella flexneri entry into epithelial cells. J. Bacteriol. 175:5899-5965.

Miller, J. H. 1971. Experiments in Molecular Genetics. Cold Spring Harbor Laboratory Press, Cold Spring Harbor, NY.

Mudgett, M. B., and Staskawicz, B. J. 1999. Characterization of the Pseudomonas syringae pv. tomato AvrRpt2 protein: demonstration of secretion and processing during bacterial pathogenesis. Mol. Microbiol. 32:927-941.

Ochman, H., Medhora, M. M., Garza, D., and Hartle, D. L. 1990. Amplification of flanking sequences by inverse PCR., p. 219-227. In: T. J. White (ed.), PCR protocols, a guide to methods and applications. Academic Press Inc., London.

Petnicki-Ocweija, T., Schneider, D., Tam, V., Chancey, S., Shan, L., Jamir, Y., Schechter, L., Janes, M., Buell, C., Tang, X., Collmer, A., and Alfano, J. 2002. Genomewide identification of proteins secreted by the Hrp type III protein secretion system of Pseudomonas syringae pv. tomato DC3000. Proc. Natl. Acad. Sci. U.S.A. 99:7652-7657.

Pirhonen, M. U., Lidell, M. C., Rowley, D., Lee, S. W., Silverstone, S., Liang, Y., Keen, N. T., and Hutcheson, S. W. 1996. Phenotypic expression of Pseudomonas syringae avr genes in E. coli is linked to the activities of the hrp-encoded secretion system. Mol. Plant-Microbe Interact. 9:252-260.

Sambrook, J., and Russell, D. W. 2001. Molecular Cloning: A Laboratory Manual. Cold Spring Harbor Laboratory Press, Cold Spring Harbor, NY, U.S.A

Sawada, H., Suzuki, F., Matsuda, I., and Saitou, N. 1999. Phylogenetic analysis of Pseudomonas syringae pathovars suggests the horizontal gene transfer of $\arg K$ and the evolutionary stability of $h r p$ gene cluster. J. Mol. Evol. 49:627-644.

Scofield, S. R., Tobias, C. M., Rathjen, J. P., Chang, J. H., Lavelle, D. T., Michelmore, R. W., and Staskawicz, B. J. 1996. Molecular basis of gene-for-gene specificity in bacterial speck disease of tomato. Science 2074:2063-2065

Shao, F., Merritt, P., Bao, Z., Innes, R., and Dixon, J. 2002. A Yersinia effector and a Pseudomonas avirulence protein define a family of cysteine proteases functioning in bacterial pathogenesis. Cell 109:575-588.

Shapiro, A., and Zhang, C. 2001. The role of NDR1 in avirulence genedirected signaling and control of programmed cell death in Arabidopsis. Plant Physiol. 127:1089-1101.

Silhavy, T. J., Berman, M. L., and Enquist, L. W. 1984. Experiments with Gene Fusions. Cold Spring Harbor Laboratory Press, Cold Spring Harbor, NY, U.S.A.

Staskawicz, B. J., Dahlbeck, D., and Keen, N. T. 1984. Cloned avirulence gene of Pseudomonas syringae pv. glycinea determines race-specific incompatibility on Glycine $\max$ (L.) Merr. Proc. Natl. Acad. Sci. U.S.A. 81:6024-6028.

Staskawicz, B. J., Dahlbeck, D., Keen, N., and Napoli, C. 1987. Molecular characterization of cloned avirulence genes from race 0 and 1 of Pseudomonas syringae pv. glycinea. J. Bacteriol. 169:5789-5794.

Stevens, C., Bennett, M., Athanossopoulos, E., Tsiamis, G., Taylor, J., and Mansfield, J. 1998. Sequence variations in alleles of the avirulence gene avrPphE.R2 from Pseudomonas syringae pv. phaseolicola lead to loss of recognition of the AvrPphE protein within bean cells and a gain in cultivar-specific virulence. Mol. Microbiol. 29:165-177.

Tang, X., Frederick, R. D., Zhou, J., Halterman, D. A., Jia, Y., and Martin, G. B., 1996. Initiation of plant disease resistance by physical interaction of AvrPto and Pto kinase. Science 274:2060-2063.

Tsiamis, G., Mansfield, J., Hockenhull, R., Jackson, R., Sesma, A., Athanassopoulos, E., Bennett, M., Stevens, C., Vivian, A., Taylor, J., and Murillo, J. 2000. Cultivar-specific avirulence and virulence function assigned to avrPphF in Pseudomonas syringae pv. phaseolicola, the cause of bean halo-blight disease. EMBO (Eur. Mol. Biol. Organ.) J. 19:3204-3214.

Van den Eede, G., Deblaere, R., Goethals, K., Van Montagu, M., and Holsters, M. 1992. Broad host range and promoter selection vectors for bacteria that interact with plants. Mol. Plant-Microbe Interact. 5:228-234.

Vivian, A., and Gibbon, M. J. 1997. Avirulence genes in plant-pathogenic bacteria: signals or weapons. Microbiology 143:693-704.

Wei, W., Plovanich-Jones, A., Deng, W.-L., Jin, Q.-L., Collmer, A., 
Huang, H. C., and He, S. Y., 2000. The gene coding for the Hrp pilus structural protein is required for type III secretion of Hrp and Avr proteins in Pseudomonas syringae pv. tomato. Proc. Natl. Acad. Sci. U.S.A. 97:2247-2252.

Xiao, Y., Heu, S., Yi, J., Lu, Y., and Hutcheson, S. W. 1994. Identification of a putative alternate sigma factor and characterization of a multicomponent regulatory cascade controlling the expression of Pseudomonas syringae pv. syringae Pss61 hrp and hrmA genes. J. Bacteriol. 176:1025-1036

Xiao, Y., and Hutcheson, S. W. 1994. A single promoter sequence recog- nized by a newly identified alternate sigma factor directs expression of pathogenicity and host range determinants in Pseudomonas syringae. J. Bacteriol. 176:3089-3091.

Yuan, J., and He, S. Y. 1996. The Pseudomonas syringae Hrp regulation and secretion system controls the production and secretion of multiple extracellular proteins. J. Bacteriol. 178:6399-6402.

Zwiesler-Vollick, J., Plovanich, J., Nomura, K., Bandyopadhyay, S., Joardar, V., Kundel, B., and He, S. 2002. Identification of novel hrp-regulated genes through functional genomic analysis of the Pseudomonas syringae pv. tomato DC3000 genome. Mol. Microbiol. 45:1207-1218. 